\title{
Inducer expulsion and the occurrence of an HPr(Ser-P)-activated sugar-phosphate phosphatase in Enterococcus faecalis and Streptococcus pyogenes
}

\author{
Jing-Jing Ye, John Minarcik and Milton H. Saier, Jr \\ Author for correspondence: Milton H. Saier, Jr. Tel: +1 619534 4084. Fax: +1 6195347108. \\ e-mail: msaier@ucsd.edu
}

Department of Biology, University of California at San Diego, La Jolla, CA 92093-0116, USA
Inducer expulsion, a phenomenon in which rapidly metabolizable sugars cause cytoplasmic dephosphorylation and efflux of pre-accumulated sugarphosphates (sugar-P), has been documented for Streptococcus pyogenes, Streptococcus bovis, and Lactococcus lactis, but not for other Gram-positive bacteria. Using intact cells and membrane vesicles, we show that Enterococcus faecalis exhibits both inducer exclusion and inducer expulsion, and that the latter phenomenon is dependent on the metabolite-activated ATP-dependent HPr(Ser) kinase that phosphorylates Ser-46 in HPr of the phosphotransferase system. A small, heat-stable, membrane-associated, HPr(Ser-P)-activated sugarP phosphatase (Pase II), previously identified only in LC. lactis, is shown to be present in extracts of Enterococcus faecalis and Streptococcus pyogenes but not in those of Staphylococcus aureus, Streptococcus mutans, Streptococcus salivarius, or Bacillis subtilis, organisms that do not exhibit the inducer expulsion phenomenon. Further, Lactobacillus brevis, an organism that exhibits inducer expulsion by a different mechanism, also apparently lacks Pase II. The results reveal that Pase II is present in those organisms that exhibit the coupled sugar-P hydrolysis/expulsion mechanism but not those that lack this mechanism. They provide correlative evidence that Pase II initiates inducer expulsion in species of enterococci, streptococci and lactococci.

Keywords: carbohydrate metabolism, transport, sugar-phosphate phosphatase, Grampositive bacteria, HPr, phosphotransferase system

\section{INTRODUCTION}

Inducer expulsion is the term given to the phenomenon wherein the addition of a metabolizable carbohydrate to the growth medium of a micro-organism elicits the rapid efflux of a pre-accumulated sugar. Two types of such mechanisms have been demonstrated in Gram-positive bacteria. In Lactobacillus brevis, the lactose and glucose permeases function by $\mathrm{H}^{+}$symport and accumulate their non-metabolizable substrates as the free (non-phosphorylated) cytoplasmic sugars. Addition of a metabolizable sugar uncouples sugar transport from $\mathrm{H}^{+}$symport, and efflux consequently occurs (Romano et al., 1987; Ye et al., 1994a, b). In contrast, in Streptococcus pyogenes and Lacto-

Abbreviations: 2DG, 2-deoxyglucose; FBP, fructose-1,6-bisphosphate; Pase I \& II, phosphatase I \& II; PEP, phosphoenolpyruvate; PTS, phosphotransferase system; TMG, thiomethyl $\beta$-D-galactopyranoside. coccus lactis, lactose and glucose are accumulated via the phosphoenolpyruvate (PEP)-dependent phosphotransferase system (PTS)-mediated group translocation mechanism, and consequently their non-metabolizable substrates accumulate in the cytoplasm as the phosphorylated derivatives (Reizer \& Panos, 1980; Thompson \& Saier, 1981). In this case inducer expulsion is a two-step process in which cytoplasmic phosphohydrolysis precedes efflux (Reizer et al., 1983).

Both types of efflux processes are mediated by a metabolite-activated ATP-dependent protein kinase that specifically phosphorylates Ser-46 in HPr of the PTS (Ye et al., $1994 \mathrm{a}-\mathrm{d})$, and $\mathrm{HPr}(\operatorname{Ser}-\mathrm{P})$ then binds to various targets of regulation such as the lactose $: \mathrm{H}^{+}$and glucose: $\mathrm{H}^{+}$symporters of Lb. brevis (Ye \& Saier, 1995a, b) and a smail, heat-stable sugar-P phosphatase of Lc. lactis (Ye \& Saier, 1995c). The phosphatase has been solubilized from the membranes of Lc. lactis, purified to near homogeneity and 
characterized (Ye \& Saier, 1995c). It is a monomeric enzyme (approx. $9000 \mathrm{Da}$ ) which apparently forms a $1: 1$ stoichiometric complex with $\mathrm{HPr}(\mathrm{Ser}-\mathrm{P})$, and this complex is more than 10 times more active than the free enzyme. Like the efflux process, the enzyme is dependent on $\mathrm{Mg}^{2+}$ but insensitive to fluoride inhibition. It has been designated phosphatase II (Pase II) to distinguish it from a different, larger, heat-sensitive phosphatase (Pase I) of Lc. lactis that is inhibited by fluoride and insensitive to HPr(Ser-P) activation (Thompson \& Chassy, 1983; Ye \& Saier, 1995c).

Little is known about the distribution of Pase II in Grampositive bacteria. Inducer expulsion has been demonstrated for Lc. lactis (Thompson \& Saier, 1981), Strep. pyogenes (Reizer \& Panos, 1980) and Strep. bovis (Cook et al., 1995), but attempts to demonstrate this phenomenon in Stapbylococcus aureus (Saier \& Simoni, 1976) and Bacillus subtilis (Deutscher et al., 1994; Fujita \& Miwa, 1994) have given consistently negative results. Moreover, although $L b$. brevis exhibits the sugar: $\mathrm{H}^{+}$symport uncoupling mechanism of inducer expulsion, its potential for catalysing the expulsion of pre-accumulated cytoplasmic sugar-Ps has not been tested. All of these Gram-positive bacteria and others are known to possess $\mathrm{HPr}$ and the $\mathrm{HPr}(\mathrm{Ser})$ kinase (Reizer et al., 1988).

In this paper we report comparative studies which demonstrate that Enterococcus faecalis cells and membrane vesicles accumulate the lactose analogue thiomethyl $\beta$-Dgalactopyranoside (TMG) as the 6-phosphate ester (TMG-6-P) and that they exhibit both inducer exclusion and inducer expulsion under conditions that result in the generation of $\mathrm{HPr}($ Ser-P) intracellularly or intravesicularly. We have further identified Pase II in extracts of both E. faecalis and Strep. pyogenes, and show that no such activity can be demonstrated in extracts of $L b$. brevis, B. subtilis, Strep. mutans, Strep. salivarius and Staph. aureus. Those bacteria that lack Pase II do not exhibit sugar-P phosphatase-dependent inducer expulsion in vivo. These results provide clear evidence to suggest that Pase II is required for inducer expulsion and occurs in a limited subgroup of the low GC Gram-positive bacteria. They lead to the conclusion that the regulatory targets of $\mathrm{HPr}($ Ser-P) action are species-specific.

\section{METHODS}

Many of the methods used have been described in our previous publications (Ye et al., 1994a-d; Ye \& Saier, 1995a-c) and are repeated here only where substantially different from the published procedures.

Enzyme assay. Sugar-P phosphatase activity was routinely determined by a modification of an earlier method (Parvin \& Smith, 1969; see Ye \& Saier, 1995c). Briefly, 10-25 $\mu$ l enzyme $(5-10 \mu \mathrm{g})$ was added to an assay solution containing $50 \mathrm{mM}$ MES buffer ( $\mathrm{pH} 7 \cdot 0$ ), $20 \mathrm{mM} \mathrm{MgSO}_{4}$ and $10-20 \mathrm{mM}$ sugar- $\mathrm{P}$. The assay solutions were incubated at $40^{\circ} \mathrm{C}$ for $10-30 \mathrm{~min}$ before $1 \mathrm{ml}$ isobutanol and $0.3 \mathrm{ml} 4.25 \%$ (w/v) ammonium molybdate in $0.43 \mathrm{M}$ sulfuric acid were added. Phosphate was extracted into the organic phase by vigorous mixing, and when the organic phase had cleared, $1 \mathrm{ml}$ was removed and mixed with $1 \mu \mathrm{l} 4 \%$ (w/v) $\mathrm{SnCl}_{2}$ in concentrated $\mathrm{HCl}$ before measure- ment of $\mathrm{OD}_{760}$. For TMG-6-P phosphatase activity measurements, $1.5 \mathrm{mM} \quad\left[{ }^{14} \mathrm{C}\right] \mathrm{TMG}-6-\mathrm{P} \quad$ [specific activity, $0.5 \mathrm{mCi} \mathrm{mmol}^{-1}$, prepared as described previously (Ye et al., 1994c)] was added and incubated for up to $2 \mathrm{~h}$ before measuring the ratio of $\left[{ }^{14} \mathrm{C}\right]$ TMG-P to free $\left[{ }^{14} \mathrm{C}\right] \mathrm{TMG}$ by ion-exchange chromatography $(5 \times 0.5 \mathrm{~cm}$ column size $)$ as outlined by Kundig \& Roseman (1971). Protein concentration was determined following the procedure of Lowry.

Organisms and growth conditions. Streptococcus pyogenes (Reizer et al., 1983), Streptococcus salivarius (ATCC 25975) (Waygood et al., 1986; Vadeboncoeur et al., 1991), Streptococcus mutans (ATCC 25175) (Mimura et al., 1987), Lactobacillus brevis (Romano et al., 1987; Ye et al., 1994a), Staphylococcus aureus (Saier \& Simoni, 1976) and Bacillus subtilis (Reizer et al., 1989) have all been described. All bacteria except $L b$. brevis were grown at $37^{\circ} \mathrm{C}$ for $16 \mathrm{~h}$ in LB medium containing $25 \mathrm{mM}$ galactose $(4 \mathrm{l}$ for a typical preparation) as described by Ye et al. (1994c). Lb. brevis was grown as described by Ye et al. (1994a) or Saier et al. (1995).

Preparation of cell extracts, membranes and partially purified enzymes. The same procedures were used for all of the bacterial species examined. Washed cell pellets, each from $4 \mathrm{l}$ growth medium, were resuspended to a volume of $60 \mathrm{ml}$ in $100 \mathrm{mM}$ HEPES buffer ( $\mathrm{pH} 7 \cdot 3$ ) containing $1 \mathrm{mM}$ EDTA, $1 \mathrm{mM}$ dithiothreitol and $5 \mathrm{mM} \mathrm{MnSO}_{4}$ (HEDM buffer) as well as $0 \cdot 1 \mathrm{mM}$ PMSF. Cells were broken by three passages through a French pressure cell $[11000$ p.s.i. (76 MPa) $]$ and debris was removed by centrifugation at $10000 \mathrm{~g}$ for $20 \mathrm{~min}$. The membranes were collected by ultracentrifugation at $200000 \mathrm{~g}$ for $90 \mathrm{~min}$.

Membranes were resuspended in HEDM buffer and treated with $8 \mathrm{M}$ urea and $4 \%(\mathrm{v} / \mathrm{v}) 1$-butanol at $0{ }^{\circ} \mathrm{C}$ for $30 \mathrm{~min}$ (Kundig \& Roseman, 1971; Saier et al., 1977). They were then centrifuged ( $200000 \mathrm{~g}$ for $90 \mathrm{~min}$ ) and the supernatants were collected and dialysed overnight against a 41 volume of $20 \mathrm{mM}$ Tris buffer $(\mathrm{pH} 7 \cdot 0)$ at $4{ }^{\circ} \mathrm{C}$.

The dialysed urea-butanol-treated supernatants ( $40 \mathrm{ml}$ each) were transferred (at a flow rate of $0.5 \mathrm{ml} \mathrm{min}^{-1}$ ) on to a DEAESephacel anion-exchange column $(3 \times 20 \mathrm{~cm})$ previously equilibrated with HEDM buffer. Proteins were eluted with a linear gradient of $0 \cdot 1-0 \cdot 4 \mathrm{M} \mathrm{NaCl}$ in HEDM buffer.

Transport in $\boldsymbol{E}$. faecalis cells and vesicles. Transport of $\left[{ }^{14} \mathrm{C}\right] \mathrm{TMG}$ into $E$. faecalis cells was conducted and membrane vesicles of $E$. faecalis were prepared as described previously for Lc. lactis (Ye et al., 1994c, d). The electroporation procedure allowing entry of proteins and metabolites into the vesicles was as described previously (Ye et al., 1994a-d).

Reagents. $\left[{ }^{14} \mathrm{C}\right] \mathrm{TMG}\left(58 \mu \mathrm{Ci} \mu \mathrm{mol}^{-1}\right)$ was from New England Nuclear $\left(\beta\right.$-D- $\left[\right.$ methyl $\left.l{ }^{14} \mathrm{C}\right]$ thiogalactopyranoside). $\left[{ }^{14} \mathrm{C}\right] \mathrm{TMG}-6-$ $P$ was prepared by using starved cells of $L c$. lactis as described by Thompson \& Saier (1981). Hydrofluor scintillation cocktail was purchased from Research Products International. Analytical grade anion-exchange resin AG1-X2 was obtained from BioRad. DEAE-Sephacel anion-exchange resin was obtained from Pharmacia. All phosphorylated compounds and other reagents were obtained from Sigma.

\section{RESULTS}

\section{Inducer exclusion and expulsion in Enterococcus faecalis cells}

Previous studies have established the phenomena of glucose-promoted inducer exclusion and expulsion in Strep. pyogenes, Strep. bovis, and Lc. lactis, but attempts to 

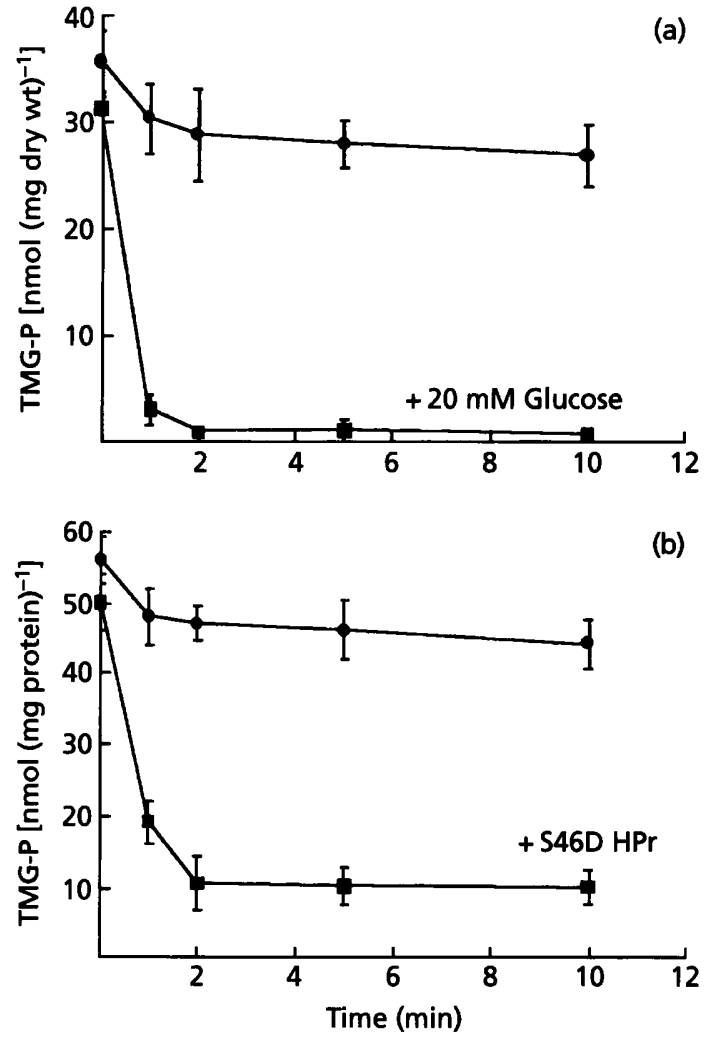

Fig. 1. Inducer expulsion in cells (a) and vesicles (b) of $E$. faecalis. (a) Time course for the expulsion of TMG-6-P from intact cells of $E$. faecalis. Cells were grown, washed, resuspended and exposed to $60 \mu \mathrm{M}\left[{ }^{14} \mathrm{C}\right] \mathrm{TMG}\left(58 \mu \mathrm{Ci} \mu \mathrm{mol}^{-1}\right)$ for $10 \mathrm{~min}$ at $30^{\circ} \mathrm{C}$ as described in Methods and in previous reports (Ye et al., 1994c, d). At $t=0$, glucose $(20 \mathrm{mM})$ was added to one culture ( $\square$ ) but not to the other (O), and efflux of the radioactive sugar was followed as a function of time. (b) Time course for the expulsion of TMG-6-P accumulated as the phosphate ester from vesicles derived from $E$. faecalis cells as described in the legend to Table 1 and in previous reports (Ye et al., 1994c, d). Retention of vesicular radioactivity was followed as a function of time following electroporation in the absence $(O)$ or presence $(\square)$ of S46D HPr $(50 \mu \mathrm{M})$.

demonstrate comparable behaviour in B. subtilis and Staph. aureus were unsuccessful (see Introduction). E. faecalis has not been examined for this phenomenon. This organism accumulates TMG as the phosphate ester (TMG-6-P) as a result of the activity of the lactose/galactose PTS. Fig. 1(a) shows a time course for glucose-promoted expulsion of TMG from E. faecalis cells. While whole cells retained $\left[{ }^{14} \mathrm{C}\right] \mathrm{TMG}-\mathrm{P}$ with a very low turnover rate in the absence of glucose, the presence of glucose promoted efflux with a half life of less than $30 \mathrm{~s}$. Efflux was preceded by intracellular TMG-P hydrolysis as reported previously for Strep. pyogenes (Reizer et al., 1983).

As shown in Table 1, column 2, several sugars, present in excess $(20 \mathrm{mM}$ inhibiting sugar as compared with $60 \mu \mathrm{M}$ TMG), strongly inhibited TMG uptake (inducer exclusion). These sugars included glucose, mannose and galactose as well as the glucose analogue, 2-deoxyglucose (2DG). Other sugars (fructose and ribose) inhibited TMG
Table 1. TMG exclusion and expulsion in E. faecalis cells

For measurement of exclusion, cell suspensions $(16 \mu \mathrm{g}$ dry wt $\mathrm{ml}^{-1}$ ) in $50 \mathrm{mM}$ Tris/maleate buffer, $\mathrm{pH} 7 \cdot 0$, were preincubated with or without $20 \mathrm{mM}$ of the sugar indicated below for $2 \mathrm{~min}$ before addition of $60 \mu \mathrm{M}\left[{ }^{14} \mathrm{C}\right] \mathrm{TMG}\left(58 \mu \mathrm{Ci} \mu \mathrm{mol}^{-1}\right)$. Uptake was measured after a $10 \mathrm{~min}$ incubation period at $30^{\circ} \mathrm{C}$. A value of 1.0 corresponds to $35.6 \mathrm{nmol}\left[{ }^{14} \mathrm{C}\right]$ TMG-6-P accumulated (mg protein $)^{-1}$. For measurement of expulsion, the cell suspensions described above were allowed to accumulate radioactive TMG $(60 \mu \mathrm{M})$ for $10 \mathrm{~min}$ before addition of the sugar $(20 \mathrm{mM})$ indicated below. Retention of radioactivity was measured after an additional $10 \mathrm{~min}$ incubation period. A value of 1.0 corresponds to $32 \cdot 1 \mathrm{nmol}\left[{ }^{14} \mathrm{C}\right]$ TMG-6-P remaining in the cells (mg protein $)^{-1}$. Values are the means of three experiments $\pm \mathrm{SD}$.

\begin{tabular}{|lcc|}
\hline Sugar added (20 mM) & \multicolumn{2}{c|}{ Relative TMG accumulation } \\
\cline { 2 - 3 } & Exclusion assay & Expulsion assay \\
\hline None & $1 \cdot 00$ & $1 \cdot 00$ \\
Glucose & $0 \cdot 06 \pm 0 \cdot 02$ & $0 \cdot 04 \pm 0 \cdot 02$ \\
Mannose & $0 \cdot 07 \pm 0 \cdot 01$ & $0 \cdot 23 \pm 0 \cdot 07$ \\
2DG & $0 \cdot 03 \pm 0 \cdot 005$ & $0 \cdot 25 \pm 0 \cdot 09$ \\
Galactose & $0 \cdot 05 \pm 0 \cdot 01$ & $0 \cdot 34 \pm 0 \cdot 11$ \\
Fructose & $0 \cdot 31 \pm 0 \cdot 12$ & $0 \cdot 44 \pm 0 \cdot 10$ \\
Ribose & $0 \cdot 36 \pm 0 \cdot 11$ & $0 \cdot 56 \pm 0 \cdot 13$ \\
Glucitol & $0 \cdot 89 \pm 0 \cdot 23$ & $1 \cdot 10 \pm 0 \cdot 15$ \\
Mannitol & $1 \cdot 04 \pm 0 \cdot 18$ & $1 \cdot 12 \pm 0 \cdot 13$ \\
\hline
\end{tabular}

uptake to a lesser extent while glucitol and mannitol were not inhibitory. In contrast, of these sugars, only glucose caused essentially all of the pre-accumulated TMG to efflux from galactose-grown cells, although several other sugars were partially effective (Table 1, column 3).

Comparable experiments were conducted with radioactive, non-metabolizable 2DG (data not shown). Uptake of the sugar analogue was strongly inhibited by glucose and mannose but not by galactose, fructose or glucitol. Similarly, glucose stimulated rapid expulsion of preaccumulated 2DG-P, but galactose, fructose, ribose and glucitol were either substantially less effective or without effect. The results establish the occurrence of selective exclusion and expulsion of both TMG and 2DG in $E$. faecalis in a fashion that resembles these phenomena reported previously for Lc. lactis, Strep. pyogenes and Strep. bovis.

\section{TMG expulsion in vesicles of $\boldsymbol{E}$. faecalis}

Previous communications from this laboratory have demonstrated the inducer expulsion phenomenon in membrane vesicles from Lc. lactis (Ye et al., 1994b, d). Efflux was not observed when either HPr or fructose-1,6bisphosphate (FBP) was electroporated into the vesicles, but the two together promoted rapid efflux. Moreover, when the S46D mutant HPr derivative, in which the phosphorylatable Ser-46 was replaced by Asp, thereby introducing a permanent negative charge at that position, was introduced into the vesicles by electroporation, efflux 
Table 2. Regulation of TMG efflux from $E$. faecalis vesicles

The effects of HPr and its mutant derivatives on TMG-6-P hydrolysis-dependent intravesicular expulsion were studied in the presence or absence of FBP, glucose-6-P or fructose-6-P. $\left[{ }^{14} \mathrm{C}\right] \mathrm{TMG}\left(60 \mu \mathrm{M}\right.$; specific activity, $\left.58 \mu \mathrm{Ci} \mu \mathrm{mol}^{-1}\right)$ uptake was allowed to occur for $10 \mathrm{~min}$ at $30^{\circ} \mathrm{C}$ before vesicle suspensions were chilled to $0{ }^{\circ} \mathrm{C}$. $\mathrm{HPr}$, or one of its mutant derivatives $(100 \mu \mathrm{M})$, with or without $20 \mathrm{mM}$ FBP, glucose-6-P or fructose6-P, as indicated below, was electroporated into the vesicles at $0{ }^{\circ} \mathrm{C}$. The samples were rapidly brought to $30^{\circ} \mathrm{C}$ and incubated at this temperature for an additional 10 min during which time efflux occurred. Remaining intravesicular TMG was then measured. Values are the means of three experiments $\pm S D$.

\begin{tabular}{|lc|}
\hline Addition* & $\begin{array}{r}\text { [14 }^{*} \text { ]TMG accumulation [nmol } \\
\left.\text { (mg protein) })^{-1}\right]\end{array}$ \\
\hline None & $0 \cdot 56 \pm 0 \cdot 03$ \\
FBP & $0 \cdot 49 \pm 0 \cdot 13$ \\
HPr & $0 \cdot 62 \pm 0 \cdot 14$ \\
HPr, FBP & $0 \cdot 15 \pm 0 \cdot 04$ \\
HPr, fructose-6-P & $0 \cdot 28 \pm 0 \cdot 02$ \\
HPr, glucose-6-P & $0 \cdot 33 \pm 0 \cdot 03$ \\
H15A HPr & $0 \cdot 57 \pm 0 \cdot 12$ \\
H15A HPr, FBP & $0 \cdot 16 \pm 0 \cdot 02$ \\
S46D HPr & $0 \cdot 14 \pm 0 \cdot 03$ \\
S46D HPr, FBP & $0 \cdot 13 \pm 0 \cdot 05$ \\
S46A HPr & $0 \cdot 66 \pm 0 \cdot 18$ \\
S46A HPr, FBP & $0 \cdot 58 \pm 0 \cdot 16$ \\
H15A S46D HPr & $0 \cdot 17 \pm 0 \cdot 01$ \\
H15A S46D HPr, FBP & $0 \cdot 16 \pm 0 \cdot 05$ \\
\hline
\end{tabular}

* $\mathrm{H} 15 \mathrm{~A}$ is a mutant $\mathrm{HPr}$ in which His-15 is replaced by Ala; in S46D, Ser-46 is replaced by Asp; in S46A, Ser-46 is replaced by Ala.

was dependent only on the intravesicular presence of the protein (Ye et al., 1994b, d).

Fig. 1(b) shows time courses for TMG expulsion from $E$. faecalis membrane vesicles. Little efflux was observed when vesicles were incubated at $30^{\circ} \mathrm{C}$, but electroporation into the vesicles of the $\mathrm{HPr}(\mathrm{Ser}-\mathrm{P})$ analogue, S46D HPr, promoted rapid efflux of the pre-accumulated TMG-6-P.

Table 2 summarizes the results of TMG efflux experiments in which several different intravesicular agents were examined. Extravesicular HPr did not stimulate TMG efflux, in either the presence or the absence of a metabolite such as FBP (data not shown). Similarly, electroporation in the presence of each of these agents alone had little effect (Table 2). However, when HPr and FBP were simultaneously electroporated into the vesicles, rapid efflux was observed (Table 2). When the mutant $\mathrm{HPr}$, in which Ser-46 was replaced by Ala (S46A HPr), replaced wild-type $\mathrm{HPr}$, no stimulation of efflux was observed, even when FBP was present. S46A HPr cannot be phosphorylated by the metabolite-activated HPr kinase. In contrast, when S46D HPr was electroporated into the vesicles, efflux occurred even in the absence of FBP, as also documented in Fig. 1(b). H15A HPr, in which the

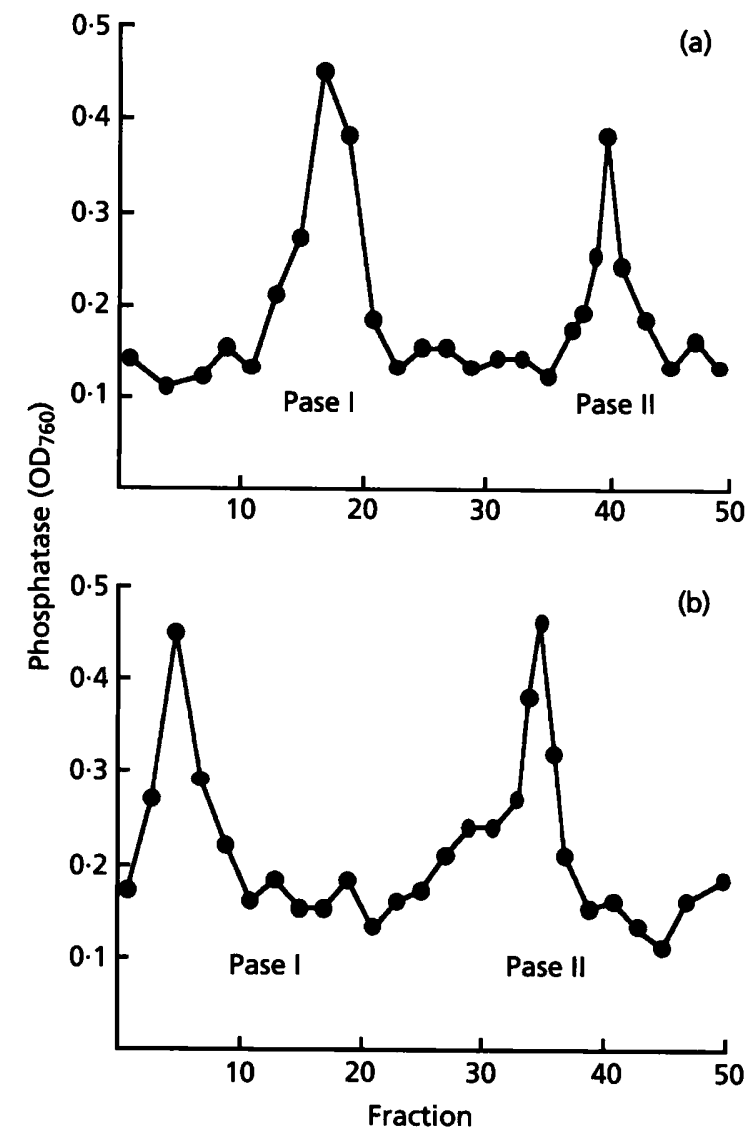

Fig. 2. Elution of phosphatase activities from DEAE-Sephacel. In both cases, extracts were prepared and membranes were extracted with urea-butanol using the procedure described in Methods. The extracted material from E. faecalis (a) and Strep. pyogenes (b) was applied to and then eluted from the DEAESephacel column with a linear salt gradient $(0.1-0.4 \mathrm{M} \mathrm{NaCl})$ and activity peaks were assayed for stimulation by S46D HPr. In both cases, stimulation was observed only for the second peak (designated Pase II; see Table 3). Similar chromatographic separation of the activities obtained from B. subtilis, Staph. aureus, Strep. mutans and Strep. salivarius each yielded a single peak of phosphatase activity which eluted before Pase II of $L C$. lactis, Strep. pyogenes or E. faecalis. None of these activity peaks exhibited S46D HPr stimulation. $L b$. brevis extracts gave two activity peaks, but neither exhibited appreciable stimulation by S46D HPr.

active site His-15 was replaced by Ala (Reizer et al., 1989), behaved like wild-type $\mathrm{HPr}$ in this respect, while $\mathrm{H} 15 \mathrm{~A}$ S46D HPr behaved like S46D HPr. In the presence of wild-type $\mathrm{HPr}$, glucose-6-P and fructose-6-P were marginally effective in promoting TMG efflux (Table 2). These results lead to the conclusion that phosphorylation of Ser-46 in HPr mediates inducer expulsion in E. faecalis as in Lc. lactis.

Presence of Pase II in E. faecalis and Strep. pyogenes, but not in B. subtilis, Staph. aureus, Lb. brevis, Strep. mutans or Strep. salivarius

The S46D-activated sugar-P phosphatase (Pase II) of $L c$. lactis can be solubilized from the membrane by urea- 
Table 3. Activation of sugar-P phosphatase activities in various preparations from Strep. pyogenes, E. faecalis and $L b$. brevis

Extracts and derived protein fractions were prepared and assayed for fructose-6-P phosphatase activity with (+) and without (-) $50 \mu \mathrm{M} \mathrm{S46D} \mathrm{HPr}$ as described in Methods. Extracts and derived protein fractions from B. subtilis and Staph. aureus were similarly assayed, but like Lb. brevis fractions, they did not exhibit measurable stimulation by S46D HPr.

\begin{tabular}{|c|c|c|c|}
\hline \multirow[t]{2}{*}{ Purification step } & \multicolumn{2}{|c|}{$\begin{array}{l}\text { Phosphatase activity [nmol } \\
\left.(\mathrm{mg} \text { protein })^{-1} \mathrm{~min}^{-1}\right]\end{array}$} & \multirow[t]{2}{*}{$\begin{array}{l}\text { Activation } \\
\text { (-fold) }\end{array}$} \\
\hline & -S46D HPr & + S46D HPr & \\
\hline \multicolumn{4}{|l|}{ E. faecalis } \\
\hline Crude extract & $25 \pm 4$ & $90 \pm 18$ & $3 \cdot 8$ \\
\hline $\begin{array}{l}\text { Supernatant from urea-butanol- } \\
\text { treated membranes }\end{array}$ & $49 \pm 13$ & $162 \pm 42$ & $3 \cdot 4$ \\
\hline \multicolumn{4}{|l|}{ DEAE-Sephacel } \\
\hline Fraction I & $190 \pm 25$ & $210 \pm 30$ & $1 \cdot 1$ \\
\hline Fraction II & $66 \pm 18$ & $444 \pm 120$ & $6 \cdot 7$ \\
\hline \multicolumn{4}{|l|}{ Strep. pyogenes } \\
\hline Crude extract & $30 \pm 1$ & $60 \pm 12$ & $2 \cdot 0$ \\
\hline $\begin{array}{l}\text { Supernatant from urea-butanol- } \\
\text { treated membranes }\end{array}$ & $73 \pm 13$ & $190 \pm 48$ & $2 \cdot 7$ \\
\hline \multicolumn{4}{|l|}{ DEAE-Sephacel } \\
\hline Fraction I & $320 \pm 66$ & $310 \pm 90$ & $1 \cdot 0$ \\
\hline Fraction II & $127 \pm 25$ & $570 \pm 130$ & $4 \cdot 5$ \\
\hline \multicolumn{4}{|l|}{ Lb. brevis } \\
\hline Crude extract & $6.2 \pm 0.7$ & $6 \cdot 6 \pm 1 \cdot 2$ & $1 \cdot 0$ \\
\hline $\begin{array}{l}\text { Supernatant from urea-butanol- } \\
\text { treated membranes }\end{array}$ & $19 \pm 2$ & $19 \pm 5$ & $1 \cdot 0$ \\
\hline \multicolumn{4}{|l|}{ DEAE-Sephacel } \\
\hline Fraction I & $72 \pm 18$ & $67 \pm 24$ & 0.9 \\
\hline Fraction II & $42 \pm 12$ & $48 \pm 6$ & $1 \cdot 0$ \\
\hline
\end{tabular}

butanol treatment (Ye \& Saier, 1995c) and the resultant protein elutes from DEAE-Sephacel at a high salt concentration, well after Pase I (Ye \& Saier, 1995c). As shown in Fig. 2, two peaks of phosphatase activity eluted from the column when an extract was prepared either from E. faecalis cells (Fig. 2a) or from Strep. pyogenes cells (Fig. 2b). The activity in peak I was not stimulated by S46D HPr in either case, but that in peak II was stimulated about tenfold by S46D HPr in both cases. Peak II therefore corresponds to Pase II.

Using our standard assay procedure, urea-butanol-extracted material from membranes of B. subtilis, Staph. aureus, Strep. mutans and Strep. salivarius each exhibited only one peak of phosphatase activity while that of $L b$. brevis exhibited two peaks (data not shown). These activities were not stimulated by S46D HPr. Activities found in crude extracts, in membranes, and in ureabutanol-extracted membranes from these organisms did not exhibit appreciable stimulation by S46D HPr. The activities from all of these organisms eluted at lower salt concentration than was observed for Pase II from $L c$. lactis, Strep. pyogenes or E. faecalis (see legend to Fig. 2 and Ye \& Saier, 1995c).

The various fractions obtained from E. faecalis, Strep. pyogenes and $L b$. brevis were assayed for stimulation of sugar-P phosphatase activity by S46D HPr. The results are summarized in Table 3. Crude extracts derived from E. faecalis or Strep. pyogenes cells exhibited sugar-P phosphatase activity that was weakly stimulated by S46D $\mathrm{HPr}$. In both cases, solubilization of the membraneassociated activities and assay of the two DEAE-Sephacel activity peaks revealed that the first peak (Fraction I) was not stimulated by S46D HPr but that the second peak (Fraction II) was stimulated several-fold (Table 3). The results suggest that the first peak corresponds to Pase I from Lc. lactis (Thompson \& Chassy, 1983), while the second peak corresponds to Pase II (Ye \& Saier, 1995c).

In a recent report we demonstrated that $L b$. brevis possesses a complete fructose-specific PTS as well as the initial enzymes of glycolysis that act on fructose-1-P, fructose 1-P kinase and FBP aldolase (Saier et al., 1995). Synthesis of the enzymes responsible for fructose ca- 
tabolism were induced under anaerobic conditions in the presence of fructose. $L b$. brevis cells were therefore grown under these conditions, and an extract was prepared for assay of sugar-P phosphatase activities. Membranes were extracted with butanol-urea, and the resultant extract was passed through a DEAE-Sephacel column as outlined in the legend to Fig. 2. Fractions with phosphatase activities were assayed with and without $50 \mu \mathrm{M}$ S46D $\mathrm{HPr}$ as indicated in the legend to Table 3. Less than twofold activation of fructose-1-P phosphatase activity was observed.

\section{DISCUSSION}

The results reported in this paper and previous communications (Saier \& Simoni, 1976; Deutscher et al., 1994; Ye et al., 1994a-d; Cook et al., 1995; Ye \& Saier, 1995a-c) reveal a perfect correlation between the occurrence of glucose-promoted, cytoplasmic, sugar-P hydrolysis-dependent inducer expulsion in intact cells of several low GC Gram-positive bacteria and the presence of S46D $\mathrm{HPr}$-stimulated Pase II in extracts derived from these cells (Table 4). Within the low GC Gram-positive bacteria, cytoplasmic sugar-P hydrolysis-dependent inducer expulsion has been easily demonstrated in species of lactococci and enterococci as well as some streptococcal species, but not in species of lactobacilli, bacilli or staphylococci or in some species of streptococci. Our attempts to measure TMG expulsion in vivo in Strep. mutans and Strep. salivarius were negative although Strep. pyogenes and Strep. bovis did exhibit this phenomenon. Moreover, as reported here, those organisms that exhibit S46D-stimulated Pase II are the same ones that exhibit the expulsion phenomenon (Table 4). Therefore, it can be postulated that it is the presence of Pase II, in addition to the low GC Gram-positive $\mathrm{HPr}(\mathrm{Ser})$ kinase, that determines the propensity of any one of these organisms for the expulsion phenomenon.

All low GC Gram-positive bacteria so far assayed for $\mathrm{HPr}$ and the ATP-dependent, metabolite-activated $\mathrm{HPr}(\mathrm{Ser})$ kinase have been found to exhibit these activities. In addition to the organisms listed in Table 4, these organisms include Acholeplasma laidlawii (Hoischen et al., 1993) and Listeria monocytogenes (Mitchell et al., 1993). The latter two organisms have not yet been assayed either for inducer expulsion or the presence of Pase II. Other low GC Gram-positive bacteria, some of which are known to possess the PTS (Romano \& Saier, 1992), have not yet been assayed for the $\mathrm{HPr}(\mathrm{Ser})$ kinase.

In contrast, high GC Gram-positive bacteria, including species of Corynebacterium, Arthrobacter, Brevibacterium and Streptomyces, all of which possess a PTS, do not exhibit demonstrable $\mathrm{HPr}(\mathrm{Ser})$ kinase activity when assayed in vitro (Titgemeyer et al., 1995; J. Reizer \& M. H. Saier, Jr, unpublished results). Escherichia coli and other enteric bacteria also lack this enzyme (J. Reizer, J. Deutscher \& M. H. Saier, Jr, unpublished results). It therefore appears that the presence of the $\mathrm{HPr}(\mathrm{Ser})$ kinase may be a characteristic feature of low GC Gram-positive bacteria.

A revealing experiment can be performed once the gene encoding Pase II has been cloned. This gene, incorporated into an appropriate plasmid, can be transferred to an organism which lacks the expulsion phenomenon (e.g., Staph. aureus or B. subtilis), and it can be determined if the presence of the plasmid allows expulsion to occur. If it does, then the presence of Pase II alone must determine sensitivity to this phenomenon. However, if rapid, glucose-promoted, cytoplasmic sugar-P phosphohydrolysis is observed without efflux, then an additional component of the efflux apparatus, a specific sugar efflux system characteristic of the organisms that naturally exhibit the phenomenon of inducer expulsion, may be required. This possibility is not unreasonable as many substrates have been shown to be taken up via transport systems that differ from their efflux counterparts (Krämer, 1994a, b). As the route of sugar efflux involved in the inducer exclusion phenomenon has not yet been defined, these experiments are likely to prove informative.

Table 4. Correlation of the occurrence of inducer expulsion in cells with the presence of S46D-stimulated Pase II in various low GC Gram-positive bacteria

\begin{tabular}{|lccc|}
\hline Organism & $\begin{array}{c}\text { Presence of HPr } \\
\text { and HPr(Ser) } \\
\text { kinase }\end{array}$ & $\begin{array}{c}\text { Occurrence of } \\
\text { inducer } \\
\text { expulsion }\end{array}$ & $\begin{array}{c}\text { Presence of } \\
\text { HPr(Ser-P)- } \\
\text { stimulated Pase II }\end{array}$ \\
\hline Lc. lactis & + & + & + \\
Strep. pyogenes & + & + & + \\
Strep. bovis & + & + & + \\
E. faecalis & + & + & - \\
Lb. brevis & + & - & - \\
Staph. aureus & + & - & - \\
B. subtilis & + & - & - \\
Strep. mutans & + & - & - \\
Strep. salivarius & + & & - \\
\hline
\end{tabular}




\section{ACKNOWLEDGEMENTS}

We thank Dr Jonathan Reizer for providing HPr and its mutant derivatives, and Mary Beth Hiller and Jackie Richardson for valuable assistance in the preparation of this manuscript. This work was supported by US Public Health Service grants 5RO1AI 21702 and 2RO1AI 14176 from the National Institutes of Allergy and Infectious Diseases. J.-J. Ye was supported by postdoctoral fellowship IF32GM16907 from the National Institutes of Health.

\section{REFERENCES}

Cook, G. M., Kearns, D. B., Russell, J. B., Reizer, J. \& Saier, M. H., Jr (1995). Regulation of the lactose phosphotransferase system of Streptococcus bovis by glucose: independence of inducer exclusion and expulsion mechanisms. Microbiology 141, 2261-2269.

Deutscher, J., Sauerwald, H., Reizer, J., Saier, M. H., Jr, Zwacka, R. \& Steinmetz, M. (1994). Loss of protein kinase catalysed phosphorylation of HPr, a phospho-carrier protein of the phosphotransferase system, by mutation of the $p t s H$ gene confers catabolite repression resistance to several catabolic genes of Bacillus subtilis. $J$ Bacteriol 178, 3338-3344.

Fujita, Y. \& Miwa, Y. (1994). Catabolite repression of the Bacillus subtilis gnt operon mediated by the CcpA protein. J Bacteriol 176, 511-513.

Hoischen, C., Reizer, J., Dijkstra, A., Rottem, S. \& Saier, M. H., Jr (1993). Presence of protein constituents of the Gram-positive bacterial phosphotransferase regulatory system in Acholeplasma laidlawii. J Bacteriol 175, 6599-6604.

Krămer, R. (1994a). Secretion of amino acids by bacteria: physiology and mechanism. FEMS Microbiol Rev 13, 75-94.

Krämer, R. (1994b). Systems and mechanisms of amino acid uptake and excretion in prokaryotes. Arch Microbiol 162, 1-13.

Kundig, W. \& Roseman, S. (1971). Sugar transport. II. Characterization of constitutive membrane-bound Enzymes II of the Escherichia coli phosphotransferase system. J Biol Chem 246, 14071418.

Mimura, C. S., Poy, F. \& Jacobson, G. R. (1987). ATP-dependent protein kinase activities in the oral pathogen Streptococcus mutans. $J$ Cell Biochem 33, 161-171.

Mitchell, W. J., Reizer, J., Herring, C., Hoischen, C. \& Saier, M. H., Jr (1993). Identification of a phosphoenolpyruvate:fructose phosphotransferase system (fructose-1-P forming) in Listeria monocytogenes. J Bacteriol 175, 2756-2761.

Parvin, R. \& Smith, R. A. (1969). Determination of inorganic phosphate in the presence of labile organic phosphates. Anal Biochem 27, 65-72.

Reizer, J. \& Panos, C. (1980). Regulation of $\beta$-galactoside phosphate accumulation in Streptococcus pyogenes by an expulsion mechanism. Proc Natl Acad Sci US A 77, 5497-5501.

Reizer, J., Novotny, M. H., Panos, C. \& Saier, M. H., Jr (1983). The mechanism of inducer expulsion in Streptococcus pyogenes: a two step process activated by ATP. $J$ Bacteriol 156, 354-361.

Reizer, J., Saier, M. H., Jr, Deutscher, J., Grenier, F., Thompson, J. \& Hengstenberg, W. (1988). The phosphoenolpyruvate:sugar phosphotransferase system in Gram-positive bacteria: properties, mechanism and regulation. CRC Crit Rev Microbiol 15, 297-338.

Reizer, J., Sutrina, S. L., Saier, M. H., Jr, Stewart, G. C., Peterkofsky, A. \& Reddy, P. (1989). Mechanistic and physiological consequences of $\mathrm{HPr}(\mathrm{Ser})$ phosphorylation on the activities of the phosphoenolpyruvate: sugar phosphotransferase system in Gram- positive bacteria: studies with site-specific mutants of HPr. EMBO J 8, 2111-2120.

Romano, A. H. \& Saier, M. H., Jr (1992). Evolution of the bacterial phosphoenolpyruvate: sugar phosphotransferase system. I. Physiologic and organismic considerations. In The Evolution of Metabolic Function, pp. 143-170. Edited by R. P. Mortlock. Boca Raton, FL: CRC Press.

Romano, A. H., Brino, G., Peterkofsky, A. \& Reizer, J. (1987). Regulation of $\beta$-galactoside transport and accumulation in heterofermentative lactic acid bacteria. J Bacteriol 169, 5589-5596.

Saier, M. H., Jr \& Simoni, R. D. (1976). Regulation of carbohydrate uptake in Gram-positive bacteria. J Biol Chem 251, 893-894.

Saier, M. H., Jr, Feucht, B. U. \& Mora, W. K. (1977). Sugar-P: sugar transphosphorylation and exchange group translocation catalysed by the Enzyme II complexes of the bacterial phosphoenolpyruvate:sugar phosphotransferase system. J Biol Chem 252, 8899-8907.

Saier, M. H., Jr, Ye, J.-J., Klinke, S. \& Nino, E. (1995). Identification of an anaerobically-induced phosphoenolpyruvate-dependent fructose-specific phosphotransferase system and evidence for the Embden-Meyerhof glycolytic pathway in the heterofermentative bacterium, Lactobacillus brevis. J Bacteriol 178, 314-316.

Thompson, J. \& Chassy, B. M. (1983). Intracellular hexose-6phosphate: phosphohydrolase from Streptococcus lactis: purification, properties, and function. $J$ Bacteriol 156, 70-80.

Thompson, J. \& Saier, M. H., Jr (1981). Regulation of methyl- $\beta$-Dthiogalactopyranoside-6-phosphate accumulation in Streptococcus lactis by exclusion and expulsion mechanisms. J Bacteriol 146, 885-894.

Titgemeyer, F., Walkenhorst, J., Reizer, J., Stuiver, M. H., Cui, X. \& Saier, M. H., Jr (1995). Identification and characterization of phosphoenolpyruvate:fructose phosphotransferase systems in three Streptomyces species. Microbiology 141, 51-58.

Vadeboncoeur, C., Brochu, D. \& Reizer, J. (1991). Quantitative determination of the intracellular concentration of the various forms of HPr, a phosphocarrier protein of the phosphoenolpyruvate: sugar phosphotransferase system in growing cells of oral streptococci. Anal Biochem 196, 24-30.

Waygood, E. B., Mattoo, R. L., Erickson, E. \& Vadeboncoeur, C. (1986). Phosphoproteins and the phosphoenolpyruvate:sugar phosphotransferase system of Streptococcus salivarius. Detection of two different ATP-dependent phosphorylations of the phosphocarrier protein HPr. Can J Microbiol 32, 310-318.

Ye, J.-J. \& Saier, M. H., Jr (1995a). Cooperative binding of lactose and $\mathrm{HPr}(\mathrm{SerP})$ to the lactose: $\mathrm{H}^{+}$permease of Lactobacillus brevis. Proc Natl Acad Sci US A 92, 417-421.

Ye, J.-J. \& Saier, M. H., Jr (1995b). Allosteric regulation of the glucose: $\mathrm{H}^{+}$symporter of Lactobacillus brevis: cooperative binding of glucose and $\mathrm{HPr}($ Ser-P). $J$ Bacteriol 177, 1900-1902.

Ye, J.-J. \& Saier, M. H., Jr (1995c). Purification and characterization of a small membrane-associated sugar-phosphate phosphatase that is allosterically activated by $\mathrm{HPr}(\mathrm{Ser}-\mathrm{P})$ of the phosphotransferase system in Lactococcus lactis. J Biol Chem 270, 16740-16744.

Ye, J. J., Reizer, J., Cui, X. \& Saier, M. H., Jr (1994a). ATPdependent phosphorylation of serine in $\mathrm{HPr}$ regulates lactose: $\mathrm{H}^{+}$ symport in Lactobacillus brevis. Proc Natl Acad Sci USA 91, 3102-3106.

Ye, J. J., Neal, J. W., Cui, X., Reizer, J. \& Saier, M. H., Jr (1994b). Regulation of the glucose: $\mathrm{H}^{+}$symporter by metabolite-activated ATP-dependent phosphorylation of $\mathrm{HPr}$ in Lactobacillus brevis. $J$ Bacteriol 176, 3484-3492.

Ye, J. J., Reizer, J., Cui, X. \& Saier, M. H., Jr (1994c). Inhibition of 
the phosphoenolpyruvate: lactose phosphotransferase system and activation of a cytoplasmic sugar-phosphate phosphatase in Lactococcus lactis by ATP-dependent metabolite-activated phosphorylation of serine- 46 in the phosphocarrier protein, HPr. J Biol Chem 269, 11837-11844.

Ye, J. J., Reizer, J. \& Saier, M. H., Jr (1994d). Regulation of 2deoxyglucose phosphate accumulation in Lactococcus lactis vesicles by metabolite-activated, ATP-dependent phosphorylation of serine-46 in HPr of the phosphotransferase system. Microbiology 140, 3421-3429.

Received 19 June 1995; revised 2 October 1995; accepted 24 October 1995. 